\title{
Pengaruh Atmosfir Toko Fast Fashion Terhadap Ketertarikan Berbelanja Pengunjung
}

\author{
Arnanti Primiana Yuniati \\ Program Studi Desain Interior, Fakultas Industri Kreatif, Telkom University. \\ Email: Arnanti@telkomuniversity.com
}

\begin{abstract}
Abstrak
Interior ritel merupakan salah satu aspek pembentuk citra merek perusahaan fast fashion. Setiap interior ritel harus merepresentasikan citra merek perusahaan diberbagai lokasi di setiap negara. Interior ritel mempengaruhi pembeli untuk berkunjung dan berbelanja pada ritel. Jurnal ini bertujuan untuk mengetahui faktor yang mempengaruhi pembeli untuk berbelanja dan mengidentifikasi peran desain dalam membentuk lingkungan toko. Dengan menggunakan metode artikel review, diketahui bahwa seluruh lingkungan toko yaitu; citra toko, desain toko, pengalaman berbelanja, dan perilaku pengguna memiliki pengaruh dalam keputusan bertransaksi. Desain ritel menjadi stimulant konsumen dalam membuat evaluasi kognitif dan respon emosi, baik itu positif dan negative, yang membuat konsumen merespon produk. Respon konsumen inilah yang menentukan terjadinya transaksi. Terdapat tahap perilaku konsumen yang mempengaruhi transaksi dan membentuk kesetiaan konsumen terhadap merek. Seluruh faktor tersebut memiliki peran penting dalam membentuk keputusan membeli produk.
\end{abstract}

Kata kunci: Perilaku belanja, pengalaman berbelanja, lingkungan belanja, fast fashion

\begin{abstract}
Retail interior among other aspects creates fast fashion company's brand image. Every retail interior must represent company's brand image in every country location. Retail interiors influence visitor to visit and shop at the retail. This journal aims to explore factors that influence shopper making purchase and to identify how design could play a role in creating store environment. With literature review method, it is found that total score environment which are store image, store design, shopping experience, and consumer behavior are likely influence shopper to make purchase. Retail design becomes a stimulant for consumer to make cognitive evaluation and emotion responses, whether positive dan negative, that makes consumer respond toward product. This consumer responses lead whether transaction will happen or not. There are several stages of consumer behavior that influence purchasing and create consumer loyalty to product. Finally, all factors are important because it promotes consumer to buy the product.
\end{abstract}

Keywords: shopping behaviour, shopping experience, store enviroment, fast fashion

\section{Pendahuluan}

Dunia mengalami perkembangan pesat di bidang ekonomi. Hal ini membuat pertumbuhan retail di berbagai bidang, termasuk perkembangan retail fashion. Sandang merupakan salah satu kebutuhan primer manusia (Maslow, 1970), oleh karena itu bisnis di bidang retail fashion sangat berkembang pesat. Perkembangan pesat ini sejalan dengan masyarakat yang mulai berpikir bagaimana cara mendapatkan baju dengan tren terupdate, harga terjangkau, dan sustainable. Oleh karena itu, beberapa perusahaan terkemuka mancanegara melihat adanya potensi bisnis di dalam bidang tersebut dan lahirlah tren yang dinamakan Fast Fashion.

Menurut Fletcher (F. J., 2008) yang dikutip dari jurnal Fast Fashion, Sustainability, and the Ethical Appeal of Luxury Brands, Fast fashion adalah "low-cost clothing collections based on 
current, high-cost luxury fashion trends-is, by its very nature, a fast-response system that encourages disposability." Dengan begitu dapat disimpulkan bahwa fast fashion merupakan pakaian dengan harga yang terjangkau, tren yang terkini, dan masa penggunaan yang relatif pendek karena merespon lingkungan tren dengan cepat.

Banyak perusahaan yang mengangkat fast fashion sebagai value utama brand mereka, namun dengan munculnya variasi brand, membuat terjadi persaingan ketat pada retail fashion. Setiap brand berlomba-lomba menawarkan sesuatu yang unik untuk konsumen, setiap brand memiliki ciri khas atau value tersendiri. Value tersebut merupakan pembentuk brand image. Brand Image ini yang akan tercitrakan dari atmosfer toko. Penting untuk memperhatikan fisik sebuah toko untuk menghasilkan pengalaman berbelanja yang baik sehingga terjadi pembelian (Howell, 2002). Namun dalam pelaksanaanya masih banyak retail fashion yang kurang dapat membentuk atmosfer yang sesuai dengan brand image perusahaan sendiri.

Brand image atau citra menurut Kotler (Kotler, Manajemen Pemasaran, Jilid 1, PT. Indeks Kelompok, 2005) adalah seperangkat keyakinan, ide, dan kesan uang dimiliki seseorang terhadap suatu objek. Suatu perusahaan harus membentuk suatu brand image yang dapat membentuk nilai yang sesuai dengan perusahaan. Pembentukan brand image tersebut dapat dicapai dengan kualitas produk, komunikasi marketing, termasuk interior retail. Sebuah interior retail dapat membentuk brand image yang tepat bagi perusahaan dan memberikan kenyamanan berbelanja bagi para pengunjung. Menurut Preston dikutip oleh Astrid K (Kusumowidagdo, 2010), setiap ruangan mempunyai atmosphere yang dapat dirasakan karena keberadaan unsur-unsur pembentuk ruang. Oleh karena itu unsur pembentuk ruang interior dapat mempengaruhi perilaku individu didalam ruang. Saat interior sebuah retail dapat dengan benar membentuk brand image dan menciptakan suasana yang sesuai, pengunjung akan merasakan kenyamanan berbelanja brand fashion tersebut dan menaikan profit penjualan.

Dalam buku Desinging To Sell oleh Vilma Barr (Barr \& Charles , 1986), membahas tentang pentingnya desain untuk turut membantu penjualan produk dalam sebuah bisnis, termasuk desain interior yang akan membentuk sebuah atmosfer. Atmosfer adalah suasana terencana yang sesuai dengan pasar sasarannya dan yang dapat menarik konsumen untuk membeli (Kotler, Manajemen Pemasaran, Jilid 1, PT. Indeks Kelompok, 2005). Suasana ini juga terjadi di dalam sebuah retail sehingga pengunjung tertarik untuk membeli produk. Atmosfer yang baik akan menimbulkan kesan tertentu yang sesuai dengan value brand, terutama membuat pengunjung menjadi seorang konsumen. Menurut Evans Berman (2007) terdapat beberapa elemen yang membentuk atmosfer seperti (1) Exterior Facilities, (2) General Interior, (3) Store Layout, (4) Interior Display, dan (5) Social Dimensions.

Dalam berbelanja, konsumen tidak hanya memperhatikan produk dari sebuah brand, tetapi juga bagaimana produk itu "dikemas". Berbelanja merupakan suatu pengalaman dimana pengunjung mengekspresikan harapan, impian, aspirasi, dan keinginan. Konsumen turut memperhatikan faktor-faktor lain, terutama faktor atmosfer di dalam suatu retail. Oleh karena itu, pengunjung akan lebih tertarik untuk berkunjung dan membeli produk disebuah retail yang memiliki atmosfer yang sesuai dengan visi mereka. Hal ini menunjukan bahwa suatu desain, khususnya atmosfer menjadi sebuah poin yang penting dalam merencanakan sebuah bisnis.

Dengan begitu, dalam perencanaan sebuah bisnis, khususnya membentuk atmosfer yang sesuai dengan brand image memjadi persoalan yang perlu diperhatikan. Perlunya suatu standar dalam perancangan elemen interior retail fashion sehingga membentuk atmosfer yang sesuai dengan brand image. Atmosfer yang sesuai akan membuat pengunjung menjadi konsumen.

\section{Metode}

Dalam penulisan artikel review ini, peneliti membutuhkan data dan referensi dari berbagai sumber. Penelitian dilandasi dengan metode pengolahan data kualitatif. Data dan referensi diambil dengan 
cara studi literature, observasi, kuesioner, dan wawancara. Metodologi ini juga akan diterapkan untuk penelitian selanjutnya

\section{Pembahasan}

\section{Retail Fast Fashion}

Perusahaan fast fashion merupakan salah satu speciality retail independen yang menunjang penjualan penjualan baju fast fashion dan servis yang baik. Menurut Berman dan Evans (Berman \& Evans, 2007), retailing merupakan suatu usaha bisnis yang berusaha memasarkan barang dan jasa kepada konsumen akhir yang menggunaannnya untuk keperluan pribadi dan rumah tangga. Produk yang dijual dalam usaha retailing adalah barang, jasa maupun gabungan dari keduanya.

Penelitian menunjukan dengan berbelanja di ritel tertentu, seorang konsumen mendapat rekreasi dan kepuasan tertentu. Dikutip dari Anderson (Anderson, 2007), retail dimana seseorang berbelanja dan mengkonsumsi sebuah produk berkaitan dengan pendapatan seseorang dan makna sosial yang ingin seseorang tampilkan (Moye \& Kincade, 2003). Dalam penelitian sebelumnya, ditemukan bahwa target pasar yang berbelanja pada kategori ritel fast fashion merupakan seorang individu yang memiliki sifat cenderung kompetitif, berani, dan peserta yang aktif dalam bersosialisasi.

\section{Total Store Enviroments}

Keseluruhan lingkungan retail merupakan kumpulan dari berbagai aspek yang berhubungan dengan isyarat sensori, kualitas servis, variasi produk, harga, dan image/sosial konteks (Baker, Parasuraman, Grewal, \& Voss, 2002). Karena banyaknya aspek tersebut, banyak peneliti yang berlomba-lomba untuk membuktikan tiap aspek dari seting ritel dan berusaha menegaskan pentingnya dari desain retail keseluruhan (Kotler, 1973). Sudah sekian lama para peneliti dan profesional marketing menerapkan pendekatan marketing (produk, tempat, promosi, dan harga) saat mengembangkan dan mempromosikan produk, brand, atau store image (Kotler, 1973). Beberapa dibawah ini merupakan bagian dari total store enviroments yang mempengaruhi konsumen dalam mengambil keputusan membeli.

\subsection{Store Image}

Store image adalah gabungan dari faktor lingkungan dan faktor sosial yang membentuk persepsi konsumen dan kepercayaan terhadap retail. Persepsi citra ritel yang dibentuk dalam pikiran konsumen sebagian adalah karena kualitas fungsional dan atribut psikologi (Martineau, 1958). Studi lain yang mengamati tingkah laku dan hubungan dengan image retail menemukan bahwa image berkembang seiring waktu melalui penguatan dan keteguhan dari kriteria penentu konsumen (Anderson, 2007). Image ritel dapat tercermin dari solusi desain yang diterapkan. Oleh karena itu dalam proses membentuk image produk, dibutuhkan solusi desain yang konsisten untuk menghasilkan sinyal positif dan repetitif. Solusi desain yang diterapkan menjadi faktor kesuksesan untuk membentuk sinyal positif dan mengakomodasi kebutuhan berbelanja konsumen.

\subsection{Store Atmosphere}

Sebuah retail memiliki sebuah lingkungan fisik yang dapat membentuk sebuah atmosfer yang tidak hanya menarik pengunjung tetapi juga merubah pengunjung menjadi pembeli. Tidak hanya atmosfer tetapi juga store layout turut berperan dalam memberikan pengalaman berbelanja pada konsumen. Disaat pengunjung bertemu dengan harapannya, maka pengunjung akan tertarik untuk melakukan transaksi dalam retail tersebut (Priyanka, Neha, \& Gauvar, 2014). 
Menurut Lamb, Hair, Mc Daniel (Lamb, 2001)pentingnya memperhatikan store atmosphere karena penampilan eceran toko membantu menentukan citra toko dan memposisikan eceran toko dalam benak konsumen. Selain itu dengan tata letak toko yang efektif dan strategis tidak hanya akan memberikan kenyamanan dan kemudahan, melainkan juga memiliki pengaruh yang besar pada pola lalu lintas pelanggan dan perilaku berbelanja.

Menurut Berman dan Evans (Berman \& Evans, 2007) untuk toko yang merupakan basic retailer atau eceran, suasana lingkungan toko itu berdasarkan karakteristik fisik yang biasanya digunakan untuk membangun kesan dan menarik pelanggan. Tidak hanya store atmosphere ruang dalam (instore) tetapi juga ruang luar (outstore) yang dapat menciptakan kenyamanan bagi pelanggan.

Berman dan Evans (Berman \& Evans, 2007) membahas cara untuk mengatur pengoperasian retail yang baik dan benar. Menurutnya store atmosphere terdiri dari lima elemen yaitu exterior facilities, general interior, store layout, interior display, dan social dimention.

\subsection{Pengalaman Berbelanja}

Dikutip dari Anderson (Anderson, 2007) banyak perusahaan yang membedakan dirinya dengan cara meningkatkan pengalaman berbelanja indoor mereka. Lingkungan berbelanja pada seting toko yang terdesain dengan baik secara langsung mempengaruhi pengalaman berbelanja konsumen. Selain itu, lingkungan berbelanja juga mempengaruhi perasaan dan reaksi emosional konsumen terhadap toko, hal ini sangat dapat meningkatkan kesetiaan konsumen dalam membeli sebuah produk. Beberapa faktor turut mempengaruhi aktivitas berbelanja. Peneliti mengetahui bahwa faktor kemewahan yang tercitrakan dari retail dapat membuat respon positif dan status sosial yang diinginkan oleh konsumen.

\subsection{Perilaku Konsumen}

Setiap harinya terjadi pembelian disebuah ritel. Para konsumen dihadapkan pada suatu keputusan untuk menentukan pilihan dalam membeli barang. Banyak peneliti dan ahli marketing yang melakukan riset untuk dapat mengetahui faktor-faktor apa saja yang mempengaruhi konsumen dalam mengambil keputusan membeli. Menurut Wilkie (Wilkie, 1994) perilaku konsumen merupakan aktivitas mental, emosi, dan fisik yang berpengaruh pada saat orang memilih, membeli, menggunakan, dan membuang produk dan jasa setelah memuaskan kebutuhan dan keinginannya.

Perilaku konsumen selalu berubah-rubah karena dipengaruhi oleh faktor lingkungan dimana dia tinggal. Latar belakang budaya, keluarga, pendidikan dan pergaulan dapat mempengaruhi keputusan pembelian seorang konsumen. Menurut Kotler (Kotler, Manajemen Pemasaran, Jilid 1, PT. Indeks Kelompok, 2005), perilaku konsumen dipengaruhi oleh beberapa faktor. Faktor-faktor tersebut terbentuk dari kesatuan unsur-unsur yang lebih kecil bagaimana manusia berperilaku dalam kehidupan ekonominya.

\begin{tabular}{|c|c|c|c|c|}
\hline No & \multicolumn{4}{|c|}{ Faktor Pembentuk Perilaku Ekonomi } \\
\hline \multirow[t]{3}{*}{1} & \multirow[t]{3}{*}{ Faktor Budaya } & Budaya & & \\
\hline & & Sub Budaya & & \\
\hline & & Kelas Sosial & & \\
\hline \multirow[t]{4}{*}{2} & \multirow[t]{4}{*}{ Faktor Sosial } & \multirow[t]{4}{*}{ Kelompok Acuan } & \multirow[t]{2}{*}{$\begin{array}{l}\text { Kelompok } \\
\text { keanggotaan: }\end{array}$} & Kelompok Primer \\
\hline & & & & $\begin{array}{l}\text { Kelompok } \\
\text { Sekunder }\end{array}$ \\
\hline & & & \multirow[t]{2}{*}{$\begin{array}{l}\text { Kelompok } \\
\text { Luar: }\end{array}$} & $\begin{array}{l}\text { Kelompok } \\
\text { Aspirasional }\end{array}$ \\
\hline & & & & Kelompok \\
\hline
\end{tabular}




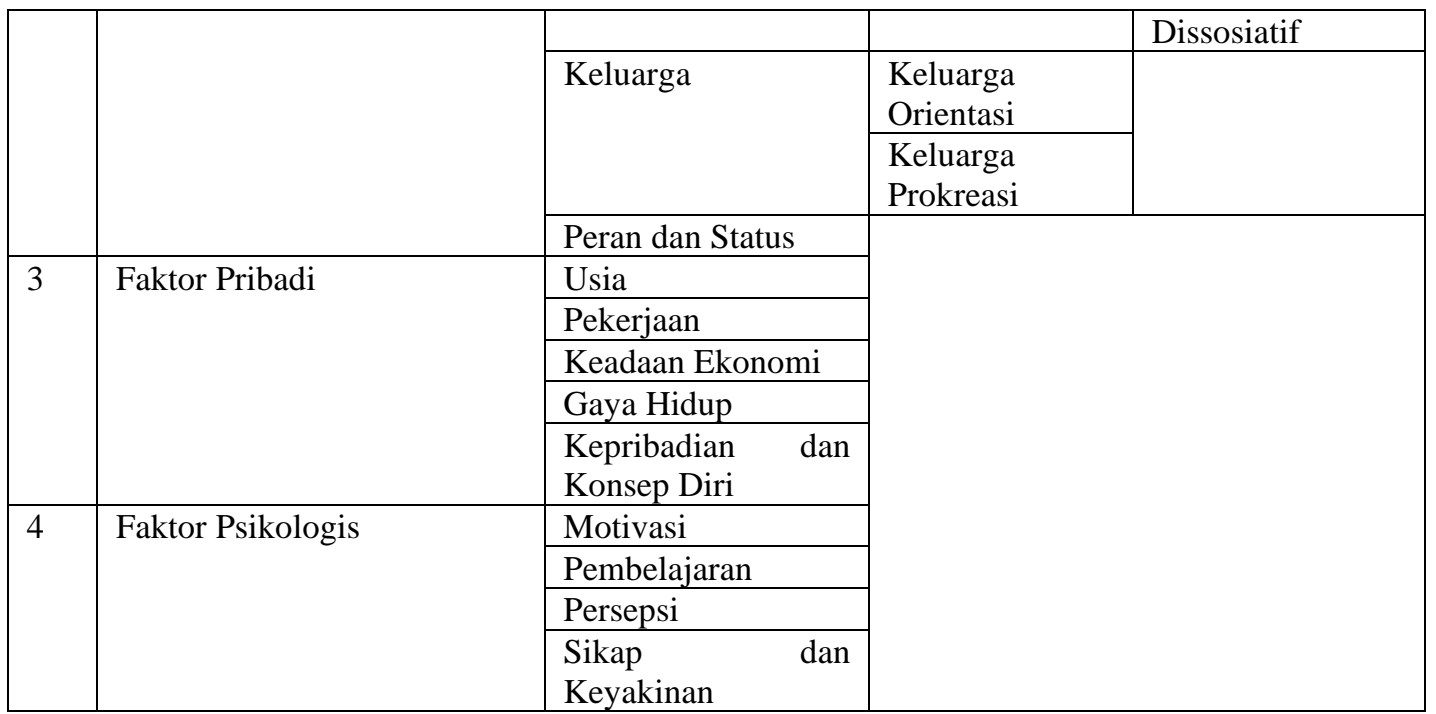

Gambar 1. Tabel Faktor Pembentuk Perilaku Ekonomi Menurut Kotler, 2005

(Sumber: Yuniati, 2020)

\section{Keputusan Pembelian Konsumen}

Pemahaman kebutuhan dan proses pembelian merupakan sesuatu yang penting diperhatikan dalam membangun strategi pemasaran efektif. Dengan mengetahui proses pengenalan masalah, pencarian informasi, evaluasi alternatif, keputusan membeli, dan perilaku pasca pembelian dapat menjadi indikator penting bagaimana cara memenuhi kebutuhan konsumen. Menurut Kotler dan Keller (2009) keputusan pembelian merupakan proses psikologi dasar dalam memahami bagaimana konsumen mengambil keputusan pembelian. Terdapat 5 tahapan yang dilalui seorang konsumen untuk mencapai keputusan pembelian.

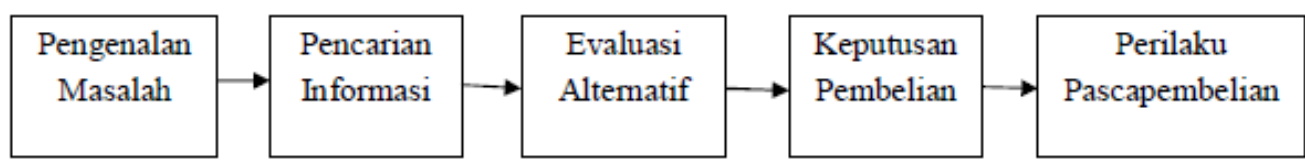

Gambar 2. Skema Tahapan Pembelian Menurut Kotler dan Keller 2013

(Sumber: Keller, 2013) 


\section{Hubungan Antara Stimuli Atmosfir, Tanggapan Emosional, dan Perilaku}

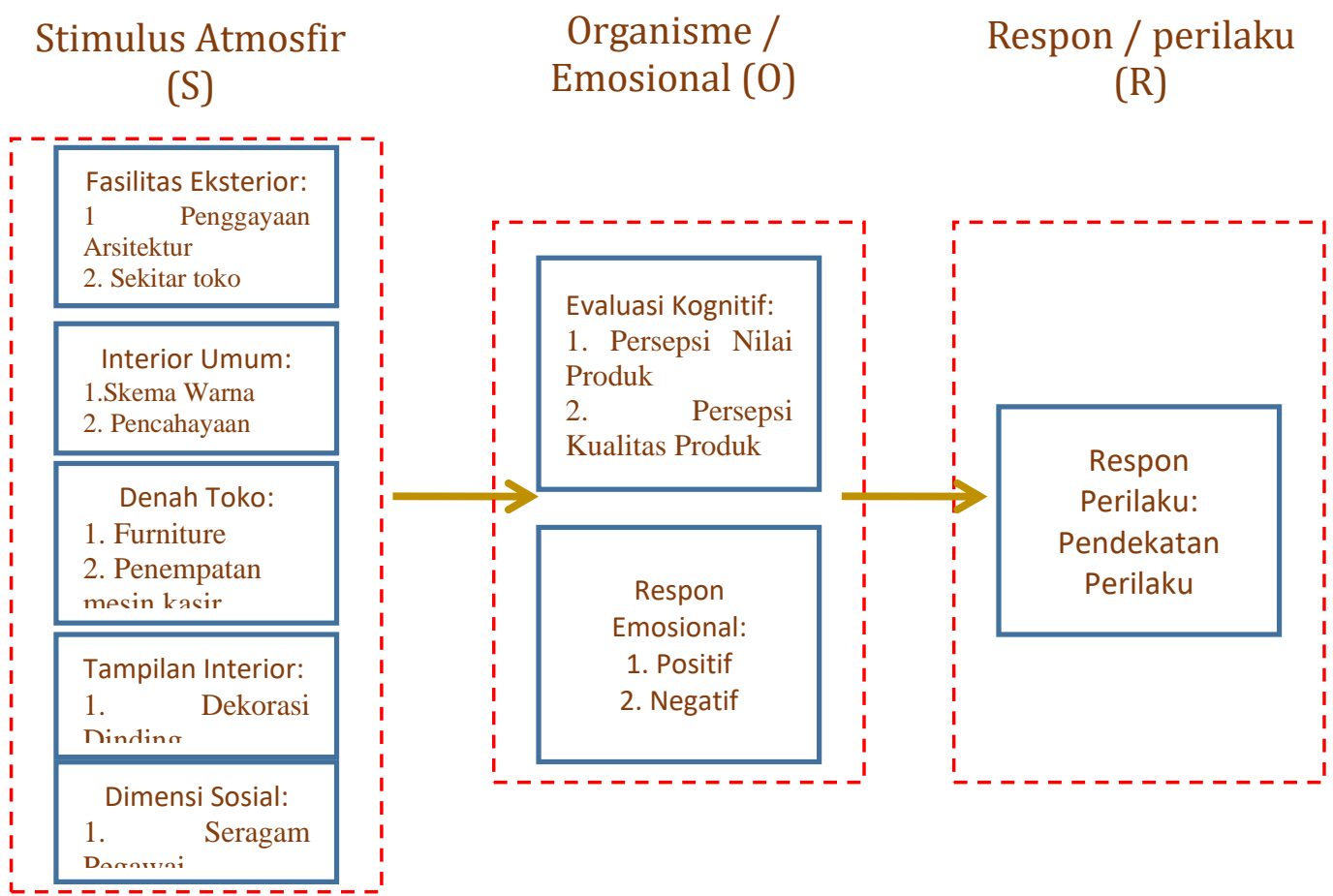

Gambar 3. Hubungan Antara Stimuli Atmosfir, Tanggapan Emosional, dan Perilaku Menurut Turley dan Miliman

(Sumber: Yuniati, 2020)

Bagan diatas merupakan bagan yang dirancang oleh Turley dan Miliman (Turley L. \&., 2000). Bagan ini merujuk pada model penelitian yang menelaah model Stimulus (S) - Organism (O) Response (R). Pada bagan ini stimuli merupakan 5 faktor fisik yang membentuk store atmosphere (Berman \& Evans, 2007). Kelima faktor ini mempengaruhi intensitas emosi (organism/O) pada pengunjung. Selanjutnya intensitas emosi ini akan berdampak pada respon perilaku pengunjung. Jika intensitas emosional positif, hal ini akan berdampak baik terhadap respon perilaku pengunjung sehingga mendukung terjadinya proses transaksi.

\section{Simpulan}

Dalam sebuah penelitian diperlukan teori dasar dan teori pendukung yang landasan meneliti. Dalam penelitian ini teori dasar mengenai faktor-faktor dan tahapan apa saja yang dibutuhkan konsumen untuk membuat keputusan pembelian. Banyaknya faktor ini menjadi alasan mengapa peneliti dan profesional marketing terus meneliti untuk mengembangkan produk mereka. Dari banyak penelitian yang ada, sedikit data yang meniliti bagaimana store atmosphere mempengaruhi keputusan membeli konsumen pada ritel fast fashion. Oleh karena itu, dibutuhkan suatu penelitian bagaimana store atmosphere mempengaruhi suasana berbelanja pada ritel fast fashion. Penelitian ini dapat dijadikan acuan untuk peneliti dan profesional marketing untuk mengembangkan produknya, khususnya produk fast fashion di Indonesia. 


\section{Daftar Pustaka}

Anderson, L. N. (2007). CASE STUDY: CUSTOMER EVALUATIONS OF INTERIOR DESIGN ELEMENTS AND MARKETING FEATURES IN AN UPSCALE WOMEN'S APPAREL BOUTIQUE. Florida: University of Florida.

Baker, J., Parasuraman, A., Grewal, D., \& Voss, G. (2002). The Influence of Multiple Store Environment Cues on Perceived Merchandise Value and Patronage Intentions. Journal of Marketing, 120-141.

Barr, V., \& Charles , E. (1986). Designing to Sell. New York: McGraw-Hill Book Company.

Berman, B., \& Evans, J. R. (2007). Retail Management : A Strategic Approach. New York: macmillan publishing company.

F. J., V. J. (2008). Fast Fashion, Sustainability, and the Ethical Appeal of Luxury Brands. Fashion Theory, 273-296.

Howell, D. (2002). Kmart: Improve the in-store experience-give the consumer a reason to return. DSN Retailing Today, Vol 41, No. 5.

Keller, K. L. (2013). Strategic Brand Management: Building, Measuring, dan Managing Brand Equity. New Jersey: Pearson Education, Inc.

Kotler, P. (1973). The Major Tasks of Marketing Management. Journal of Marketing, 42-49.

Kotler, P. (2005). Manajemen Pemasaran, Jilid 1, PT. Indeks Kelompok. Jakarta: Gramedia.

Kusumowidagdo, A. (2010). Pengaruh Desain Atmosfer Toko terhadap Perilaku Belanja: Studi atas Pengaruh Gender terhadap Respon Pengunjung Toko. Integritas, 17-32.

Lamb, W. C. (2001). Pemasaran. Jakarta: Salemba Empat.

Levi, \& Weitz. (2001). Retailing Management. USA: McGraw-Hill.

Martineau, P. (1958). The Personality of Retail Store. Harvard Bussiness Review, 47-55.

Maslow, H. A. (1970). Motivation and Personality . New York: Harper \& Row Publisher.

Moye, L. N., \& Kincade, D. H. (2003). Shopping Orientation Segments: Exploring Differences in Store Patronage and Attitude toward Retail Store Environments among Female Apparel Consumers. International Journal of Consumer Studies, 278-299.

Priyanka, S., Neha, K., \& Gauvar, V. (2014). Retail Shoppability: The Impact of Store Atmospherics and Store Layout On Consumer Buying Patterns. International Journal od Scientific \& Technology Research, 15-23.

Sulistya, M., \& Sari, S. M. (2013). Perwujudan Brand Image dalam Penataan Interior Rotelli Shoes di Galaxy Mall. Jurnal Intra., 1-6.

Turley, L. \&. (2000). Atmospheric Effect on Shopping Behavior: A Review Of The Experimental Evidence. Journal of Bussiness Research, 193-211.

Turley, L. W., \& Milliman, R. (2002). Atmospheric Effect on Shopping Behavior: A Review Of The Experimental Evidence. Journal of Bussiness Research, 193-211.

Wilkie, W. L. (1994). Consumer Behavior. New York: John Wiley and Son . 
Lintas Ruang: Jurnal Pengetahuan \& Perancangan Desain Interior | Vol.8 No.1 2020 | Hal 23-29 